\begin{tabular}{|c|c|c|}
\hline st & $\begin{array}{l}\text { CARADDE: Jurnal Pengabdian Kepada Masyarakat } \\
\text { https://journal.ilininstitute.com/index.php/caradde } \\
\text { Volume 1 | Nomor 2 | Februari | 2019 } \\
\text { e-ISSN: } 2621-7910 \text { dan p-ISSN: } 2621-7961 \\
\text { DOI: } \text { https://doi.org/10.31960/caradde.v1i2.34 }\end{array}$ & $\begin{array}{l}\text { Iin } \\
\text { CARADDE }\end{array}$ \\
\hline
\end{tabular}

\title{
Karang Taruna Fajar : Cinderamata Bioplastik Khas Pantai Madasari, Masawah
}

\author{
Endang Surahman ${ }^{1}$, Vita Meylani ${ }^{2}$, Lucky Radi Rinandiyana ${ }^{3}$
}

\begin{tabular}{l}
\hline Keywords: \\
Bioplastik; \\
Cinderamata; \\
Karang Taruna; \\
Desa Masawah. \\
Corespondensi Author \\
1) Program Studi Pendidikan \\
Kependudukan dan Lingkungan \\
Hidup, Pascasarjana, Universitas \\
Siliwangi \\
2) Program Studi Pendidikan Biologi, \\
FKIP, Universitas Siliwangi \\
3) Program Studi Manajemen, FE, \\
Universitas Siliwangi \\
Jl. Siliwangi No. 24 Tasikmalaya \\
Surel: e.surahman.unsil.ac.id
\end{tabular}

History Artikel

Received: Oktober-2018;

Reviewed: November-2018

Accepted: Desember-2018

Published: Februari-2019

\begin{abstract}
Abstrak. Cinderamata merupakan suatu hal yang harus ada di sebuah tempat wisata. Pantai Madasari sebagai tempat wisata baru memiliki sumber daya hayati yang melimpah namun belum memiliki cinderamata sehingga perlu dikembangkan sumber daya hayati menjadi suatu cinderamata. Tujuan dari kegiatan ini adalah melatih pemuda Karang Taruna Fajar Desa Masawah membuat bioplastik dengan memanfaatkan sumber daya hayati yang ada di Pantai Madasari untuk dijadikan cinderamata khas wisata Pantai Madasari. Kegiatan ini diikuti oleh 30 orang pemuda selama 6 jam. Kegiatan awal berupa pemaparan teori pembuatan bioplastik dan praktek pembuatan bioplatik. Hasil akhir dari kegiatan ini adalah berbagai bentuk bioplastik yang dapat dijadikan cinderamata dari Pantai Madasari. Kesimpulan kegiatan ini adalah program pelatihan pembuatan bioplastik sebagai cinderamata bagi karang taruna Desa Masawah telah berhasil dilaksanakan, terbukti dengan banyaknya hasil bioplastik yang telah dibuat oleh anggota karang taruna.
\end{abstract}

(c) (1) This work is licensed under a Creative Commons Attribution

4.0 International License

\section{PENDAHULUAN}

Pantai Madasari yang terletak di Desa Masawah Kecamatan Cimerak Kabupaten Pangandaran Provinsi Jawa Barat. Akan tetapi, akses masuk ke lokasi tersebut dapat melalui Desa Masawah maupun Desa Legokjawa sehingga kedua desa memiliki peranan yang cukup penting bagi kemajuan lokasi wisata tersebut. Akses masuk melalui Desa Masawah dapat ditempuh dari belokan arah kiri di Desa Cimerak sedangkan akses melalui Desa Legokjawa dapat ditempuh melalui jalan belokan ke kiri tepat di depan Desa Legokjawa yang selanjutnya akan melewati jembatan dan pacuan kuda nasional dan sebelah kanan jalan disajikan pantai yang indah sepanjang menuju pantai Madasari sehingga jalur ini lebih banyak dipilih pengunjung sebagai alternatif akses menuju Pantai Madasari. Meskipun demikian akses melalui Desa Masawah juga masih menjadi pilihan utama bagi wisatawan karena jalurnya yang lebih dekat dari Pantai Batukaras.

Bioplastik adalah suatu bentuk plastik yang berasal dari sumber daya hayati yang bersifat biodegradable (Azhar, 2007). Bioplastik dapat berupa awetan kering mahluk hidup yang berada dalam plastik sehingga tidak akan rusak dalam waktu ratusan tahun 
(Surahman, et al., 2018). Bioplastik dapat dibentuk beranekaragam seperti gantungan kunci, hiasan meja, bahkan media pembelajaran. Oleh karena itu, bioplastik dapat dibuat dengan mengembangkan kreativitas dan inovasi pembuat sesuai kebutuhan dan keinginan pembuatnya.

Permasalahan yang dihadapi oleh mitra adalah mereka memiliki kawasan yang potensi wisatanya bagus yaitu Pantai Madasari sehingga banyak dikunjungi oleh wisatawan baik lokal maupun mancanegara akan tetapi belum memiliki cinderamata khas daerah tersebut. Selain itu, potensi sumberdaya alam yang banyak dan belum termanfaatkan dengan baik sehingga dibiarkan begitu saja. Disisi lain, masyarakat usia produktif (karang taruna) masih banyak yang belum memiliki pekerjaan yang tetap sehingga masih harus diberdayakan.

Berdasarkan uraian tersebut perlu adanya sebuah usaha untuk memberikan pengetahuan dan keterampilan kepada Karang Taruna Fajar Desa Masawah untuk dapat mengelola sumberdaya alam yang ada menjadi cinderamata yang dapat dijadikan oleh-oleh khas Pantai Madasari berbentuk bioplastik sehingga masyarakat produktif dapat diberdayakan, sumberdaya alam dapat termanfaatkan dan kawasan pantai Madasari memiliki cinderamata khas.

\section{METODE}

Untuk mencapai tujuan IbM tentang pembuatan bioplastik untuk cinderamata bagi Karang Taruna Fajar Desa Masawah menggunakan metode penyuluhan dan pelatihan langsung. Para pemuda diberikan penyuluhan mengenai bioplastik, cara membuat bioplastik, dan pelatihan langsung membuat bioplastik.

Waktu yang diperlukan untuk melakukan penyuluhan dan pelatihan adalah lima bulan dengan waktu pertemuan rutin dalam satu bulan dua hari yaitu hari sabtu dan minggu sehingga seluruhnya 10 pertemuan. Waktu yang dibutuhkan selama lima bulan dikarenakan dalam kurun waktu tersebut peserta dianggap sudah cukup memiliki keterampilan membuat bioplastik. Karena dalam masa itu kegiatan dilakukan secara rutin. Rombongan pelatihan dibagi menjadi 6 kelompok, masing-masing kelompok terdiri dari 5 orang peserta.Skema penyuluhan dan pelatihan yang dilaksanakan adalah sebagai berikut :

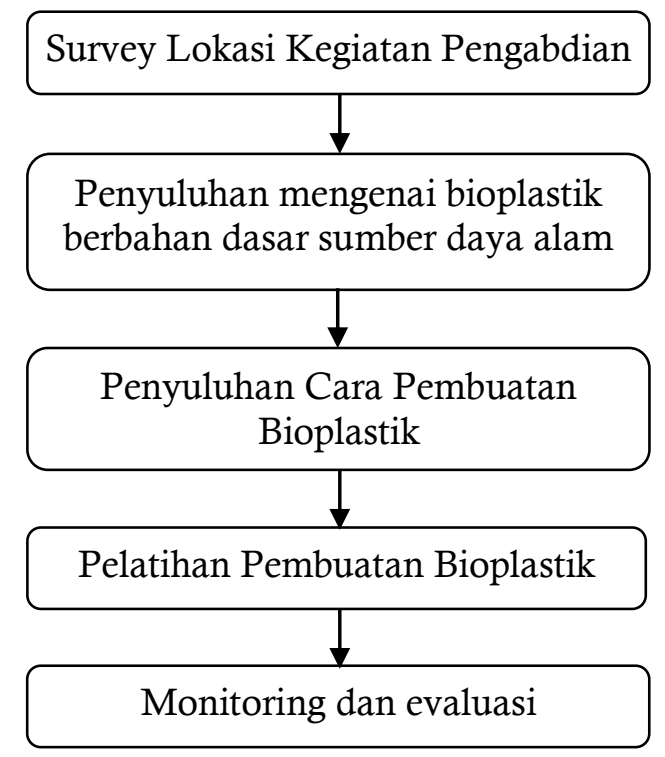

Gambar 1. Bagan Alir Kegiatan Pengabdian

Prosedur kerja yang dilaksanakan adalah satu kali untuk survey lokasi kegiatan, dua kali pertemuan untuk penyuluhan, empat kali untuk pelatihan membuat bioplastik, dan tiga kali untuk monitoring dan evaluasi pelaksanaan hasil penyuluhan dan pelatihan.

Partisipasi mitra adalah menyeleksi peserta workshop sehingga yang diikutsertakan adalah anggota Karang Taruna Fajar Desa Masawah yang mewakili berbagai Dusun yang ada di Desa Masawah.

\section{HASIL DAN PEMBAHASAN}

Desa Masawah terletak di Kecamatan Cimerak, Kabupaten Pangandaran (Anonim, 2017). Desa Masawah dengan topografi dataran dan perbukitan memiliki ketinggian rata-rata 0-95 mdpl. Bentuk morfologi desa di bagian timur berupa dataran pantai, dataran rendah dan semakin ke barat merupakan dataran bergelombang dan perbukitan. Wilayah Desa Masawah berada di Kecamatan Cimerak Kabupaten Pangandaran Provinsi Jawa Barat, dengan luas wilayah \pm $1.847 .900 \mathrm{~m}^{2}$. Desa Masawah sebelah utara berbatasan dengan Desa Batukaras, sebelah selatan berbatasan dengan Desa Batumalang dan Desa Legokjawa, sebelah barat 
berbatasan dengan Desa Batumalang dan Desa Cimerak serta sebelah timur berbatasan dengan Samudera Indonesia (Anonim, Tanpa Tahun). Sebagian besar penduduknya bermata pencaharian sebagai petani dan nelayan.

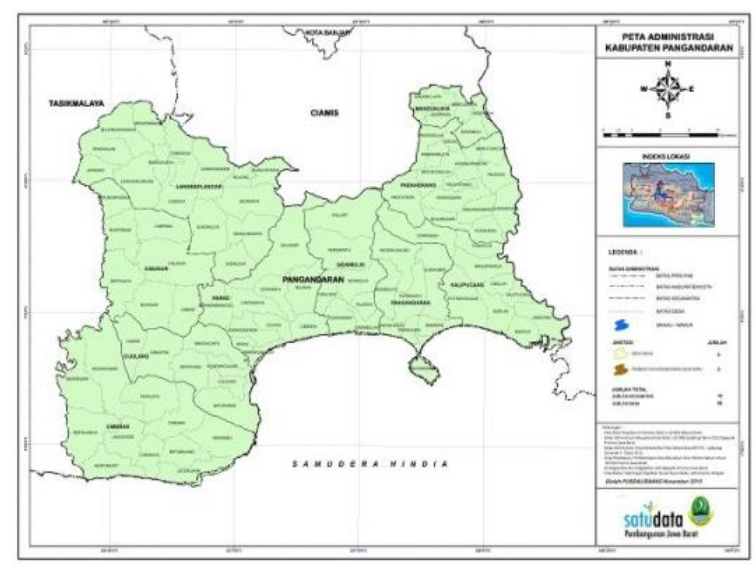

Gambar 2. Peta Kabupaten Pangandaran

Kondisi Desa Masawah yang berbatasan langsung dengan Samudra Indonesia menyebabkan sumber daya lautnya tinggi. Selain itu di sisi utara yang berbatasan dengan Desa Batukaras dan di sisi selatan berbatasan dengan Desa Legokjawa menyebabkan Desa Masawah menjadi tempat yang strategis menuju Pantai Madasari dan menuju lokasi wisata yang lain seperti Pantai Batukaras dan Pacuan Kuda Desa Legokjawa (Anonim, tanpa tahun).

Akan tetapi, kondisi ini belum dapat dimanfaatkan lebih oleh masyarakat Desa Masawah. Sehingga masyarakat Desa Masawah perlu diberdayakan, salah satunya melalui pemberdayaan Karang Taruna Fajar untuk membuat cinderamata bioplastik berbahan dasar sumber daya alam hayati yang ada di sekitar Desa Masawah melalui kegiatan pengabdian kepada masyarakat yang dilakukan oleh Tim PPM Program Studi Pendidikan Biologi, FKIP Universitas Siliwangi.

Kegiatan ini berlangsung melalui lima tahap dimulai kegiatan survey lokasi, penyuluhan mengenai cinderamata bioplastik berbahan dasar sumber daya alam hayati, penyuluhan cara membuat bioplastik, pelatihan membuat bioplastik, dan monitoring dan evaluasi. Kegiatan pertama adalah survey lokasi yang dilakukan oleh Tim PPM Program Studi Pendidikan Biologi, FKIP Universitas Siliwangi secara langsung dating ke Desa Legokjawa dan melakukan wawancara langsung dengan Ketua Karang Taruna Fajar dan melakukan tinjauan lokasi serta mencari berbagai sumber daya alam yang selanjutnya akan digunakan pada pertemuan ke empat. Hasil ini menjadi dasar dalam mengembangkan kegiatan yang akan dilaksanakan

Kegiatan kedua yang dilakukan adalah melakukan penyuluhan mengenai cinderamata bioplastik berbahan dasar sumber daya alam hayati. Hasil penyuluhan pertama menunjukkan sikap antusiasme pemuda Karang Taruna Fajar terhadap materi yang disampaikan. Hal tersebut ditandai dengan banyaknya jumlah pemuda yang hadir pada saat penyuluhan dan adanya interaksi komunikatif yang menarik antara pemateri dengan pemuda Karang Taruna Fajar yang hadir. Hal tersebut menunjukkan bahwa pemuda Karang Taruna Fajar di Desa Masawah membutuhkan bimbingan dan arahan untuk dapat memanfaatkan sumber daya alam hayati yang ada dilikngkungannya menjadi sesuatu yang lebih bernilai.

Kegiatan ketiga dan ke empat mengenai penyuluhan cara membuat bioplastik sebagai cinderamata untuk oleholeh khas Pantai Madasari berbahan dasar algae, kerang-kerangan serta tumbuhan dan hewan yang ada di lingkungan sekitar. Hasil kegiatan menunjukkan bahwa pemuda Karang Taruna Fajar sangat antusias dalam menerima materi dan memperoleh ilmu baru mengenai pembuatan bioplastik selain itu banyak diantara pemuda yang berencana memanfaatkan pembuatan cinderamata bioplastik sebagai sumber usaha dalam berbagai bentuk gantungan kunci, hiasan, dan bahkan bentuk-bentuk sebagai alat rumah tangga seperti asbak. Hasil ini selain dapat digunakan sebagai souvenir juga dapat dijadikan medida pembelajaran (Suharsono et al., 2016)

Berikut ini adalah beberapa contoh cinderamata yang dibuat oleh Pemuda Karang Taruna Fajar Desa Masawah: 

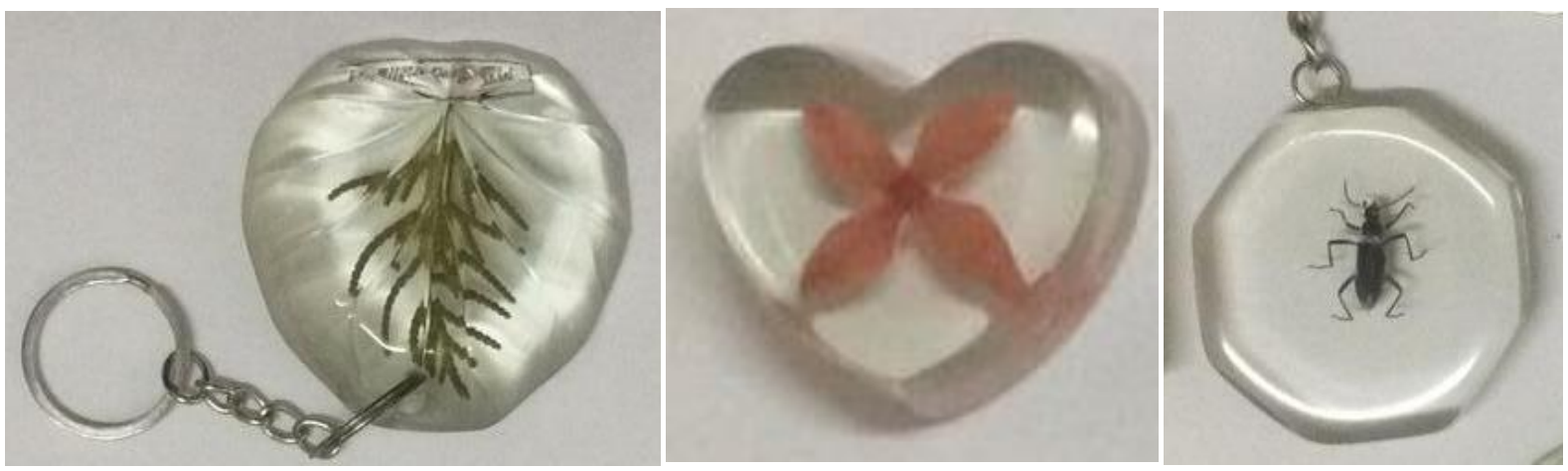

Gambar 3. Gantungan Kunci Bioplastik

Gambar 3 menunjukkan bahwa bahan dasar yang digunakan oleh pemuda Karang Taruna Fajar adalah kerang-kerangan dan hewan yang ada di lingkungan sekitar. Bahan dasar ini banyak ditemukan di daerah sekitar Desa Masawah, dan sudah tidak digunakan bahkan dapat dikategorikan sebagai sampah. Melalui kegiatan ini bahan-bahan yang tadinya dianggap tidak bernilai diubah menjadi sesuatu yang lebih bernilai.

Hasil dari kegiatan ini menunjukkan adanya peluang usaha baru bagi masyarakat Desa Masawah melalui pemanfaatan bahanbahan yang ada di lingkungan sekitardan dapat dijadikan cinderamat oleh-oleh khas tempat wisata Pantai Madasari. Namun dalam memanfaatkan peluang ini terdapat beberapa hal yang harus disiapkan diantaranya peluang usaha, peluang usaha yang dimaksud adalah masyarakat harus dapat membuat sesuatu yang baru yang dapat dijadikan peluang usaha yang cukup menjanjikan bagi masyarakat sekitar tentunya masyarakat harus lebih kreatif menciptakan sesuatu. Persiapan dan modal, untuk dapat mencapai usaha tersebut tentunya diperlukan persiapan dan modal. Persiapan ini dapat berupa keterampilan, bahan dan strategi penjualan sedangkan modal diperlukan untuk dapat menunjang hal tersebut. Jenis cinderamata, jenis cinderamata yang dibuat haruslah sesuatu yang berbeda dan dapat menjadi ciri khas dari tempat wisata tersebut sehingga masyarakat perlu memikirkan jenis cinderamata apa yang harus mereka buat dan pasarkan (Anonim, 2014).

Variasi bentuk dan bahan yang digunakan merupakan salah satu alternative untuk meningkatkan omzet usaha yang sedang dirancang (Khairani, 2018). Selain itu, pembuatan bioplastik ini merupakan salah satu bentuk wirausaha masyarakat (Marufi 2018) yang diinisiasi oleh kegiatan Pengabdian Kepada Masyarakat dari Universitas Siliwangi dan Karang Taruna.

Hasil akhir dari kegiatan Pengabdian pada Masyarakat yang dilaksanakan di Desa Masawah sebagai pusat kegiatan pengabdian menghasilkan beberapa produk cinderamata bioplastik dalam berbagai bentuk. Cinderamata yang dibuat adalah gantungan kunci bioplastik yang berbahan dasar algae, kerang-kerangan, tumbuhan dan hewan yang ada di sekitar Desa Masawah. Hal tersebut dikarenakan tempat wisata di sekitar Desa Masawah (Pantai Madasari) belum memiliki cinderamata oleh-oleh khas tempat wisata tersebut. Oleh karena itu, dengan adanya kegiatan PPM membuat gantungan kunci bioplastik dari bahan-bahan yang ada di sekitar Desa Masawah sangat membantu masyarakat terutama Karang Taruna Fajar untuk mengembangkan potensi wilayahnya.

Hasil evaluasi dari kegiatan tersebut produk yang dibuat oleh peserta diantaranya menghasilkan produk yang cukup bagus akan tetapi ada juga yang masih mengalami kesulitan antara lain hewan atau tumbuhan yang dijadikan objek gantungan kunci rusak karena penambahan katalis yang melebihi batas yang dianjurkan. Selain itu, beberapa produk yang dibuat terlalu lama kering karena pada saat pembuatan bioplastik antara lapisan dasar dengan lapisan penutup tidak sesuai waktu yang seharusnya sehingga pada bagian tertentu campuran bahannya tidak kering merata, dan dalam proses penghalusan para peserta masih kesulitan memperoleh hasil yang maksimal. Hal tersebut dianggap wajar karena sebagian besar peserta baru membuat gantungan kunci berupa bioplastik sehingga 
masih perlu keberlanjutan pelatihan pembuatan bioplastik.

\section{SIMPULAN DAN SARAN}

Berdasarkan kegiatan yang sudah dilaksanakan oleh Tim Pengabdian Kepada Masyarakat Skim Ipteks Bagi Masyarakat (PPM IbM) dengan kegiatan Pelatihan Pembuatan Cinderamata Bioplastik berbasis sumberdaya alam lokal diperoleh kesimpulan antara lain terbentuknya kelompok masyarakat yang dapat mengembangkan cinderamata berupa bioplastik sebagai oleholeh berbahan dasar tumbuhan atau hewan; mulai tumbuhnya keterampilan Karang Taruna dalam mengembangkan cinderamata bioplastik yang juga dapat dijadikan sumber usaha yang lain; tersedia cinderamata bioplastik algae, kerang-kerangan, tumbuhan dan insect di Desa Masawah; memfasilitasi Karang Taruna Fajar Desa Masawah untuk lebih mengembangkan cinderamata bioplastik berbahan dasar sumber daya alam yang ada di sekitar Desa Legokjawa.

\section{UCAPAN TERIMAKASIH}

Ucapan terimakasih kami sampaikan kepada Kemenristekdikti dengan Skim Program Kemitraan Masyarakat dan difasilitasi oleh LP2M PMP Universitas Siliwangi Tahun 2018. Serta dibantu oleh Karang Taruna Fajar dan teman-teman Mahasiswa (Renaldy Rachman \& Narendra Wijaya) sehingga Kegiatan Pengabdian Kepada Masyarakat ini dapat berjalan lancar.

\section{DAFTAR RUJUKAN}

Anonim. (tanpa tahun). https://id.wikipedia.org/wiki/Masa wah,_Cimerak,_Pangandaran
Anonim.

http://iwaralaba.com/2014/04/pel uang-usaha-jual-cinderamata-ditempat-wisata/

Anonim.

http://kknm.unpad.ac.id/legokjawa /2017/07/26/profil-desalegokjawa/

Azhar, Arsyad. (2007). Media Pembelajaran. Jakarta : Raja Grafindo Perkasa.

Khairani, S., \& Pratiwi, R. (2018). Peningkatan Omset Penjualan Melalui Diversifikasi Produk dan Strategi Promosi Pada UMKM Kerajinan Souvenir Khas Palembang. Caradde Jurnal Pengabdian Kepada Masyarakat. 1(1).

Marufi, Ma'rufi., Ilyas, M., Anas, A., \& Islamiyah, R.Y. (2018). Program Pengembangan Kewirausahaan Fakultas Keguruan dan Ilmu Pendidikan. Caradde Jurnal Pengabdian Kepada Masyarakat. 1(1).

Suharsono., Surahman, E., \& Putra, R.R. (2016). Pelatihan Penggunaan Alat dan Bahan Laboratorium IPA bagi Guru IPA di Lingkungan SMP/MTs Se-Kecamatan

Cikatomas

Kabupaten Tasikmalaya. Jurnal Siliwangi Seri Pengabdian. 2 (2).

Surahman, E., Meylani, V., Rinandiyana, L.R. (2018). Pelatihan Membuat Bioplatik sebagai Cinderamata Khas Pantai Madasari Bagi Karang Taruna Samudra Desa Legokjawa. Prosiding Seminar Nasional dan Diskusi Panel Multidisiplin Hasil Penelitian \& Pengabdian Kepada Masyarakat. 1(1). 